\title{
A CAPSULATE STAPHYLOCOCCUS AUREUS
}

\author{
A. C. ScotT* \\ University Department of Bacteriology and Immunology \\ at the Western Infirmary, Glasgow
}

\section{Plates XXII-XXIV}

THIs paper describes some of the characters of a capsulate coagulase-positive staphylococcus isolated from a human wound infection.

Pathogenic staphylococci with large capsules are rare; only three strains have been described in detail. Gilbert (1931) isolated a Gram-positive coccus from samples of peritoneal and pericardial fluid taken post mortem from a young man who died with ulcerative gonococcal endocarditis. The organism had the morphology of a staphylococcus except that it had a well-defined capsule about $1 \mu \mathrm{m}$ thick which was easily visible in thin India ink suspensions. The strain grew well on ordinary media to produce large, smooth, translucent and confluent colonies, brilliant orange in colour. It fermented glucose but not mannitol and it liquefied gelatin. Colonies on blood agar were surrounded by a zone of haemolysis. Coagulase production was not tested.

Oesterle (1936) isolated a Gram-positive coccus from a sample of pus, the source of which was not known although it was probably human. Morphologically this strain was a typical staphylococcus except for the presence of a large capsule, easily visible in India ink preparations. The strain grew well on ordinary media at $22^{\circ}$ and at $37^{\circ} \mathrm{C}$ to produce orange mucoid colonies, slimy in consistency, which flowed over the agar surface on prolonged incubation. It fermented glucose, sucrose and lactose, but not mannitol; it liquefied gelatin and it clotted milk. Colonies showed zones of haemolysis on nutrient agar containing the blood of sheep, ox, horse or man, but not rabbit. This strain coagulated plasma, although it did so more slowly than freshly isolated noncapsulate strains of Staphylococcus aureus. It was not lysed by a single strain of staphylococcal bacteriophage tested, and did not produce phage lysis of 10 strains of $S$. aureus when tested by cross-plating.

Henriksen (1948) cultured a Gram-positive coccus from the throat of a patient with chronic rhino-pharyngitis. The organism had a distinct capsule, grew well on ordinary media to produce moist, mucoid, confluent colonies of a thin and non-viscid consistency which varied in colour from pure white to yellow. The strain fermented glucose, sucrose, lactose and mannitol; it liquefied gelatin and it clotted litmus milk. It was not haemolytic on blood agar. It coagulated plasma in $90 \mathrm{~min}$.

Received 29 Oct. 1968; accepted 5 Dec. 1968.

* Present address: Bacteriology Department, University of Dundee.

J. MED. MICROBIOL.-VOL. 2 (1969) 


\section{MATERIALS AND METHODS}

Organisms. The capsulate coccus, designated strain M, was isolated in January 1962 , by Dr D. D. Smith, from an infected hand laceration. Primary culture also yielded a $\beta$-haemolytic streptococcus of Lancefield's group A.

A non-capsulate variant derived from strain $M$ in the laboratory (see below) was also studied. It is designated strain D.

Staphylococcus aureus strain S193N4 (kindly supplied by the late Professor I. R. W. Lominski) was used in serological studies. This strain possesses the capsular antigen common to strain Smith (Smith and Dubos, 1956) and the related "Smith-like" strains (Koenig and Melly, 1965).

Culture media. A laboratory-produced horse-heart infusion broth containing 1 per cent. $p$-aminobenzoic acid (" nutrient broth") was used. This was solidified by the addition of 1.2 per cent. w/v agar ("Oxoid", Oxoid Ltd, London) to produce " nutrient agar". "Blood agar" was produced from the latter medium by the addition of 10 per cent. sterile defibrinated horse blood, and "serum agar" by the addition of 20 per cent. (v/v) sterile human serum. Tests of antibiotic sensitivity were carried out on "Oxoid" sensitivity test agar, and bacteriophage studies were done with a medium containing peptone 2 per cent. $(\mathrm{w} / \mathrm{v})$, sodium chloride $0.5 \mathrm{per}$ cent. and calcium chloride $200 \mu \mathrm{g}$ per $\mathrm{ml}$, solidified with 0.7 per cent. agar.

Colonial morphology was studied on the media described above after incubation at $37^{\circ} \mathrm{C}$ for 24-72 hr. Cell morphology was studied in smears stained by Gram's method, in smears stained with nigrosin and rose bengal (Browning and Mackie, 1949) and in thin India ink suspensions (Duguid, 1951) containing 2 per cent. rose bengal. Average capsule thickness was measured in thin India ink suspensions with a calibrated eyepiece graticule.

Studies of physiological and biochemical characters. Utilisation of glucose aerobically and anaerobically was tested by the method described by the Subcommittee on Taxonomy of Staphylococci and Micrococci (Report, 1965) except that anaerobic cultures were incubated in a McIntosh and Fildes jar in an atmosphere of hydrogen. The production of acid from other carbohydrates, the production of acetoin, the final $p \mathrm{H}$ produced in glucose broth, the production of catalase and phosphatase, and growth in human serum and in the presence of 6 per cent. sodium chloride were tested with the media and methods described by BairdParker (1963). The base composition of the deoxyribonucleic acid (DNA) of strain M was assessed by the thermal denaturation method of Marmur and Doty (1962).

Coagulase production. Production of clumping factor (" bound coagulase ") was tested by the method of Cadness-Graves et al. (1943), and soluble coagulase production by the method of Fisk (1940). Soluble coagulase production was also studied in nutrient broth cultures incubated at $37^{\circ} \mathrm{C}$ on an orbital shaker moving at 110 r.p.m. with a throw of $3 \mathrm{~cm}$ ("shaken cultures"). Supernatants from shaken cultures were concentrated by precipitation with 3 vol. of ethanol at $4{ }^{\circ} \mathrm{C}$, and the precipitate was redissolved to one-tenth of the original volume in phosphate-buffered saline $p \mathrm{H} \mathrm{7.0} \mathrm{(Hendry,} \mathrm{1948).} \mathrm{Unconcentrated} \mathrm{and} \mathrm{con-}$ centrated shaken culture supernatants were tested for clotting activity, in the presence and absence of heparin (" Pularin ", Evans Medical Ltd, Speke, Liverpool), by the method of Lominski et al. (1962).

$\alpha$-Haemolysin production. Cultures were prepared by the method of Burnet (1930). Doubling dilutions were made in $0.5-\mathrm{ml}$ volumes of a diluent containing $25 \mathrm{ml}$ nutrient broth, $74 \mathrm{ml}$ physiological saline $(0.85$ per cent. $\mathrm{NaCl}$ in distilled water), and $1 \mathrm{ml}$ of aqueous 1 per cent. " Thiomersal " (sodium ethylmercurithiosalicylate, British Drug Houses, London). To these were added $0.5-\mathrm{ml}$ volumes of 2 per cent. suspensions of thrice-washed rabbit, sheep or human erythrocytes in aqueous 0.85 per cent. $\mathrm{NaCl}$. The mixtures were incubated in a waterbath at $37^{\circ} \mathrm{C}$ for $1 \mathrm{hr}$ and the end-point the tube showing 50 per cent. haemolysis and considered to contain 1 minimal haemolytic dose (MHD) $\}$ estimated by eye. Reaction mixtures involving sheep erythrocytes were placed thereafter at $4^{\circ} \mathrm{C}$ and examined after $23 \mathrm{hr}$ for "hot-cold" lysis. Preparations that lysed rabbit erythrocytes were retested after incubation with staphylococcal $\alpha$-antitoxin (Burroughs Wellcome, London), and staphylococcal $\alpha$-toxin (Burroughs Wellcome) was included in control tests. 
Susceptibility to bacteriophage was assessed by a standard technique (Williams and Rippon, 1952) with 25 typing strains of bacteriophage. Antibiotic sensitivity was assessed by a surface disk diffusion method.

Virulence was measured in experiments with Swiss white mice, " Porton " strain, of either sex, weighing between 20 and $25 \mathrm{~g}$. Challenge doses consisted of cells from overnight nutrient broth cultures washed thrice with broth and resuspended in broth. The number of viable cells was determined by the method of Miles and Misra (Miles, Misra and Irwin, 1938). The LD50 was determined by intraperitoneal injection of graded doses in groups of 10 mice; each group was observed for 10 days after challenge.

Agglutinating antisera. Laboratory-bred chinchilla rabbits, $2-3 \mathrm{~kg}$ in weight and of either sex, received intravenous injections of washed cells from overnight broth cultures washed thrice with saline and killed by heating at $100^{\circ} \mathrm{C}$ for $5 \mathrm{~min}$. Suspensions for injection were standardised by estimation of opacity to contain $5 \times 10^{9}$ cells per ml. Opacity was estimated by visual comparison with Brown's tubes and the conversion factor applied was that given for non-capsulate strains. An injection of $0.5 \mathrm{ml}$ was given intravenously on the first 3 days of each of three successive weeks. Fresh suspensions were prepared at the beginning of each week. Ten days after the last injection, the rabbits were bled, and the sera were heated at $56^{\circ} \mathrm{C}$ for $30 \mathrm{~min}$. and stored at $4^{\circ} \mathrm{C}$. Serum taken before injection of cells served as a control. Each serum was titrated for agglutinins by preparing serial doubling dilutions, volume $0.5 \mathrm{ml}$, in 0.85 per cent. $\mathrm{NaCl}$, adding an equal volume of a suspension of heatkilled cells containing $1 \times 10^{9}$ cells per $\mathrm{ml}$ as judged by opacity, incubating for $1 \mathrm{hr}$ at $37^{\circ} \mathrm{C}$, and allowing the tests to stand at room temperature for a further $23 \mathrm{hr}$. The end-point, the highest dilution of serum causing agglutination, was estimated by eye.

Agglutinating sera were absorbed with homologous or heterologous cells by adding equal volumes of serum diluted 1 in 2 with physiological saline to a saline suspension containing $5 \times 10^{10}$ cells per ml, incubating the mixtures for $1 \mathrm{hr}$ at $37^{\circ} \mathrm{C}$ and thereafter removing the cells by centrifugation. Absorbed sera were retested for agglutinins as described above; those that agglutinated homologous cells were reabsorbed.

Specific capsular reaction. One loopful of (i) cells from an overnight nutrient broth culture, (ii) serum, and (iii) 1 per cent. aqueous methylene blue, were mixed together on a slide; a coverslip was applied and the preparation was examined microscopically under reduced light.

Production of non-capsulate variants. Two methods were tested: (a) serial subcultures of strain $M$ were made on nutrient agar and variant colonies examined in thin India ink suspensions; $(b)$ several $100-\mathrm{ml}$ portions of nutrient broth were seeded with cells from a single colony of strain $\mathrm{M}$ cultured on nutrient agar. The cultures were incubated at $37^{\circ} \mathrm{C}$; one of them was marked and subcultured daily on to nutrient agar, and variant colonies were examined in thin India ink suspensions. When colonies formed of non-capsulate cocci were found, the remaining broth cultures were subcultured and variant colonies examined in the same way. One non-capsulate variant, designated strain $\mathrm{D}$, was selected for further study.

Reversion of the non-capsulate variant. Mice were challenged with graded intraperitoneal doses of strain D. Mice that died during the experimental period of 10 days, and those surviving challenge, were examined by culturing samples of peritoneal exudate and heart blood on blood agar. Similar samples were examined microscopically in thin India ink suspensions and after staining with nigrosin and rose bengal.

\section{RESULTS}

\section{Characterisation of the capsulate strain $M$}

Colonial morphology. Colonies of strain M after 24 hours' incubation on nutrient agar were $2-3 \mathrm{~mm}$ in diameter, translucent, domed, with an entire edge (fig. 1) and a mucoid but not sticky consistency, emulsifying easily in saline. On nutrient agar the colonies were greyish-white in colour; on blood agar or carbohydrate-containing media, colonies were greyish-yellow; yellow 
pigmentation became more obvious the longer incubation was continued. After 48-72 hours' incubation on all solid media the colonies became watery and spread over the surface of the agar. When cultured in nutrient broth, the strain produced a smooth, even suspension without pellicle formation, and a large mucoid deposit which was easily resuspended.

Cell morphology. Smears prepared from cultures grown in nutrient broth or on nutrient agar and stained by Gram's method contained Gram-positive cocci with an average diameter of $1 \mu \mathrm{m}$, arranged singly, in pairs and small clumps; clumps were rarely seen in smears of broth cultures. All the cells were enclosed by a distinct capsule with an average thickness of $0.8-1 \cdot 2 \mu \mathrm{m}$ (fig. 2). Pairs and clumps of cells were enclosed in a common capsule. Loose slime was not seen. The capsule was evident about all cells at all stages of the growth cycle, irrespective of the medium used for culture or the temperature of incubation.

Physiological and biochemical characters. Strain $\mathrm{M}$ grew well at $37^{\circ} \mathrm{C}$ on all media tested. Growth also took place at $22^{\circ}$ and at $42^{\circ} \mathrm{C}$ but was less profuse. The strain was catalase-positive. It utilised glucose aerobically and anaerobically with the production of acid, and produced acid from maltose and mannitol but not lactose. It liquefied gelatin, produced phosphatase and acetoin; cultures in glucose broth attained a final $p \mathrm{H}$ value of 4.8 . It grew in human serum and in the presence of 6 per cent. w/v NaCl. DNA of strain $\mathrm{M}$ had a guanidine-cytosine content of 37-39 moles per cent.

Coagulase production. Strain $\mathrm{M}$ did not clump in the slide test for clumping factor ("bound coagulase"). When first isolated it clotted diluted citrated human plasma in the Fisk test for soluble coagulase. In dilutions up to 1 in 64, concentrated supernatants of shaken cultures clotted both (i) citrated human plasma containing heparin, and (ii) a mixture of 0.1 per cent. fibrinogen and 1 per cent. coagulase activator.

Haemolysin activity. Haemolysin preparations were active against red cells of rabbit and man but virtually inactive against red cells of sheep. In a typical experiment, rabbit red cells were lysed by a haemolysin preparation diluted up to 1 in 64 and human red cells by dilutions up to 1 in 32, but sheep red cells were not lysed by concentrations of less than 1 in 2 . In neutralisation experiments, the same amount of antitoxin neutralised 6.25 MHD of commercial staphylococcal $\alpha$-toxin and 6.4 MHD of strain M rabbit erythrocyte lysin.

Susceptibility to bacteriophage. Strain $M$ was not lysed by any of 25 staphylococcal typing bacteriophages applied at routine test dilution (RTD) or 1000 times RTD.

Antibiotic sensitivity. In antibiotic disk sensitivity tests, strain $\mathrm{M}$ was found to be sensitive to penicillin (1.5 units), ampicillin $(25 \mu \mathrm{g})$, tetracycline $(50 \mu \mathrm{g})$, chloramphenicol $(50 \mu \mathrm{g})$, erythromycin $(10 \mu \mathrm{g})$, cloxacillin $(5 \mu \mathrm{g})$, streptomycin $(10 \mu \mathrm{g})$, cephaloridine $(5 \mu \mathrm{g})$, fucidin $(10 \mu \mathrm{g})$, lincomycin $(10 \mu \mathrm{g})$, soframycin $(10 \mu \mathrm{g})$ and neomycin $(10 \mu \mathrm{g})$, and resistant to sulphonamide $(500 \mu \mathrm{g})$, colistin $(200 \mu \mathrm{g})$ and polymyxin B (100 units).

Virulence for mice. Three different suspensions of strain $\mathrm{M}$ were standardised to contain $2 \times 10^{9}$ cells per $\mathrm{ml}$ on the basis of opacity determined by visual 
comparison with Brown's tubes; the conversion factor applied was that given for non-capsulate strains. Viable counts determined in parallel by the method of Miles and Misra showed that the suspensions contained respectively $0.71 \times 10^{9}$, $0.79 \times 10^{9}$ and $0.76 \times 10^{9}$ colony-forming units (c.f.u.) per m1. Variable factors considered at this stage of the study include (i) the presence of dead cells, (ii) the propensity of staphylococci to clump, and (iii) the disintegration of clumps during dilution procedures. It was estimated that the range of variation in the actual challenge doses was $\pm 6 \times 10^{3}$ c.f.u., and the LD50 of strain $M$ for mice challenged intraperitoneally was $\left(5 \times 10^{6}\right) \pm\left(6 \times 10^{3}\right)$ c.f.u.

Specific capsular reaction. Cells of strain $\mathbf{M}$ suspended in undiluted homologous antiserum with an agglutinin titre of 256 gave a rapid specific capsular reaction.

\section{Isolation and characters of non-capsulate variants}

Attempts to isolate non-capsulate variants by serial daily subcultures were unsuccessful after 90 subcultures and were discontinued. However, subculture of nutrient broth cultures incubated continuously for 28 days yielded numerous colonies composed of non-capsulate organisms and morphologically distinct from colonies of the capsulate strain. One variant, designated strain $\mathrm{D}$, was studied exclusively.

Apart from the absence of a capsule, strain $D$ differed from strain $M$ in three major respects: it clumped in plasma in the slide test for bound coagulase; it was susceptible to routine staphylococcal typing phages, typing at $1000 \mathrm{RTD}$ as a group-I strain of phage-type $52 / 52 \mathrm{~A} / 80 / 81$; and it was about 100 times less virulent for mice on intraperitoneal challenge, the LD50 being about $6.5 \times 10^{8}$ c.f.u.

The LD50 of strain D could not be assessed accurately. A challenge dose of less than $1 \times 10^{8}$ c.f.u. killed none of the mice, and less than half of the challenged mice died when the dose was increased to $4 \times 10^{8}$ c.f.u. With doses of $6.5 \times 10^{8}$ c.f.u., more than half of each challenged group died, but culture of peritoneal washings or heart blood from all the mice that died yielded capsulate cocci indistinguishable from strain $\mathbf{M}$ on subsequent testing (fig. 3 ). Capsulate cocci were not recovered from mice that survived challenge.

\section{The serological relation of strain $M$ to strain $D$ and strain $S 193 N 4$}

The results of homologous and cross-absorption agglutination tests with rabbit antisera are shown in the table.

These results are interpreted as showing that (i) though antisera to strain $M$ contained antibodies to both capsular and cellular antigens, antisera to strain D contained antibody to cellular antigens only; and (ii) the capsular antigen of strain $\mathrm{M}$ is distinct from that of strain S193N4.

\section{DISCUSSION}

Many of the biological characters of strain $\mathbf{M}$, and in particular the base composition of its DNA, are those of modal strains of the species Staphylococcus 
aureus. Strain $\mathrm{M}$ does not conform to the modal type in its colonial morphology, in its lack of clumping factor, its resistance to standard typing bacteriophages, and in its greater virulence for mice when injected intraperitoneally. These abnormal features are related to the presence of a thick capsule; that the capsule is indeed responsible for them is shown by the reactions of the noncapsulate variant strain $\mathrm{D}$ which possesses clumping factor, is susceptible to standard bacteriophages, is less virulent for mice on intraperitoneal injection and which in its colonial morphology and general characters is indistinguishable from modal strains of the species.

TABLE

Results of cross-absorption agglutination tests showing the serological relation of Staphylococcus aureus strain M to strain D and strain S193N4

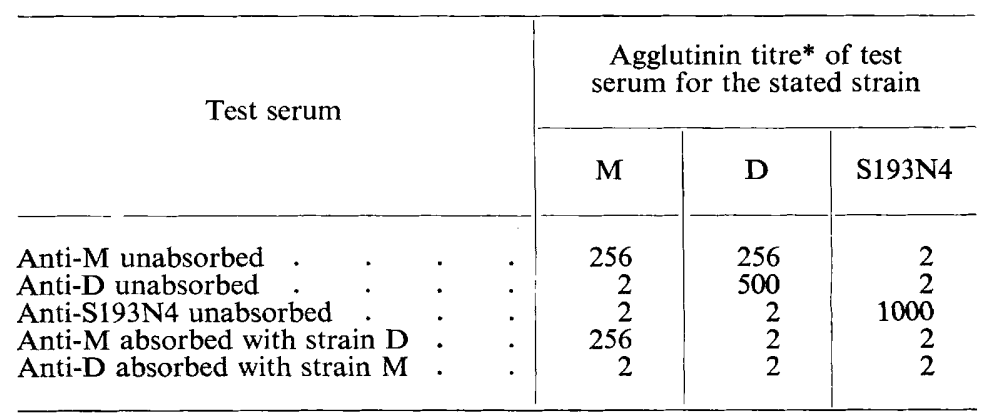

* The reciprocal of the greatest dilution causing visible agglutination is given.

The heavily capsulate strains described by Gilbert (1931), Oesterle (1936) and Henriksen (1948) cannot be accepted unequivocally as strains of Staph. aureus when judged by modern criteria. The belief that these strains were typical of the species Staph. aureus, according to the criteria in use at the time of their isolation, is, however, implicit in the descriptions of Gilbert and of Henriksen, and explicit in Oesterle's statement that non-capsulate variants of his strain had the biological properties of the typical form of Staph. pyogenes aureus ("eine Normalform ... mit den biologischen und kulturellen Eigenschaften eines typischen Staphylococcus pyogenes aureus"). There are sufficient grounds for the belief that these three strains, and strain $\mathrm{M}$ described here, differ from modal strains of the species only by their possessing a capsule.

The capsulate strain described by Gilbert dissociated to yield non-capsulate variants when cultures were stored in an ice-box. Like the non-capsulate variant derived from strain $M$, they were less virulent than the parent form and " occasionally" reverted to the parent capsulate form on animal passage. As noted above, the strain described by Oesterle also dissociated to produce noncapsulate variants, but Oesterle does not state whether he compared their virulence with that of the parent form, nor whether the variants reverted on animal passage. Henriksen's strain remained stable for $2 \mathrm{yr}$ during subculture on solid media; in this respect it may be similar to strain $M$ which was apparently stable during subculture on solid media. Strain $D$, the non-capsulate variant of strain $M$, reverted to the capsulate form when injected into mice but only 
when doses greater than $1 \times 10^{9}$ c.f.u. were injected; this suggests that the change to the parent type was due to mutation.

In its resistance to bacteriophage, unusual colonial morphology, failure to clump in plasma, and high mouse virulence when injected intraperitoneally, strain M resembles staphylococcus strain "Smith" (Smith and Dubos, 1956) and the related "Smith-like" strains (Alami and Kelly, 1959; Tompsett, 1961; Rogers and Melly, 1962; Koenig and Melly, 1965). These rare strains, of which twelve have been described in detail (Koenig and Melly) differ from modal strains by producing two colonial variants, "diffuse " and " compact", when cultured in soft, 0.15 per cent. agar containing 1 per cent. plasma. The diffuse colony variants possess a common extra surface antigen (Morse, 1963), demonstrable serologically and in some strains morphologically as a distinct capsule (Koenig and Melly; Mudd, 1965). The diffuse variants are relatively or completely resistant to staphylococcal bacteriophages, are of greater virulence for mice than modal strains when injected intraperitoneally, lack clumping factor, and dissociate readily to produce compact colony variants. The compact colony variants, by contrast, are indistinguishable from modal strains of Staphylococcus aureus except that they revert readily to the diffuse type (Hunt and Moses, 1958). From the present writer's study of one " Smith-like" strain, in which the two colonial variants could be distinguished on solid media, it appears that one cell in approximately 300 is of the opposite type (Scott, unpublished observations). Strain $M$ does, however, differ from strain "Smith" and the "Smith-like" group in the thickness and antigenic composition of its capsule, and the rate at which it dissociates to produce noncapsulate variants.

Although " Smith-like" strains are rare, Fisher (1957) has shown that many normal human sera contain antibody that acts as an opsonin for the Smith surface antigen. This finding has led Rogers (1962) to suggest that many or all coagulase-positive staphylococci may elaborate capsular antigens when growing in vivo but lose the capacity to do so when cultured on laboratory media. If modal strains of $S$. aureus do indeed form extra surface antigens during growth in vivo there is, by implication, a three-fold classification of staphylococci with respect to capsulation: the rare mucoid strains, e.g., strain $\mathrm{M}$, that consistently produce large amounts of capsular material in vivo and in vitro and interchange with the non-capsulate form at a low rate; the "Smith-like" strains, which also produce capsular material in vivo and in vitro, but interchange with the non-capsulate form with greater frequency; and the non-capsulate, modal strains, which may elaborate capsular antigens when growing in vivo but apparently fail to do so when cultured on laboratory media. It remains to be determined whether these three types form part of a continuous or discontinuous series.

\section{SUMMARY}

A capsulate staphylococcus designated strain $M$ is described. Apart from the presence of a capsule, this strain has most of the biological properties of typical strains of Staphylococcus aureus. 
Strain M differs from modal strains of $S$. aureus in its colonial morphology, resistance to bacteriophage, greater virulence for mice and failure to clump in plasma. These differences are attributed to the presence of a thick capsule.

Non-capsulate variants, produced by prolonged culture in nutrient broth, were indistinguishable from typical strains of $S$. aureus, but reverted to the parent capsulate form when passaged in mice.

Strain $\mathrm{M}$ is compared with three heavily capsulate strains previously described, and with staphylococcus strain "Smith", and the "Smith-like" strains of $S$. aureus.

The capsulate strain $\mathbf{M}$ has been deposited in the National Collection of Type Cultures (no. 10649).

I am indebted to Professor D. D. Smith who isolated the capsulate coccus, to the late Professor I. R. W. Lominski for invaluable advice and criticism, and to Mr Frank Garrity of the Microbiology Department, Catholic University, Washington, D.C., who carried out the DNA base composition analyses.

\section{REFERENCES}

Alami, S. Y., AND Kelly, F. C.

BAIRD-PARKER, A. C.

Browning, C. H., AND Mackie, T. J.

Burnet, F. M.

Cadness-Graves, Bessie, Williams, R.,

Harper, G. J., ANd Miles, A. A.

DUGUID, J. P.

FISHER, M. W.

FISK, A.

Gilbert, IsABELle

HENDRY, E. B

Henriksen, S. D.

Hunt, G. A., And Moses, A. J.

Koenig, M. G., AND Melly, M. ANN

Lominski, I., Smith, D. D., ScotT, A. C.,

Arbuthnott, J. P., Gray, S., Muir,

D., Turner, G. H., And Hedges, C. K.

Marmur, J., AND DOTY, P. .

Miles, A. A., MisRa, S. S., AND IRWIN, J. $\mathrm{O}$.

Morse, S. I.

Mudd, S. .

Oesterle, $\mathbf{P}$.

REPORT

ROGERS, D. E.

ROGERS, D. E., AND MELLY, M. ANN

SMITH, J. M., AND Dubos, R. J.

TOMPSETT, $\mathbf{R}$.

WILliams, R. E. O., AND RIPPON, JOAN E.
1959. J. Bact., 78, 539.

1963. J. Gen. Microbiol., 30, 409.

1949. Textbook of bacteriology, London, p. 785.

1930. J. Path. Bact., 33, 1.

1943. Lancet, 1, 736.

1951. J. Path. Bact., 63, 673.

1957. Antibiotics Chemother., 7, 315.

1940. Br. J. Exp. Path., 21, 311.

1931. J. Bact., 21, 157.

1948. Edinb. Med. J., 55, 142.

1948. Acta path. microbiol. scand., 25, 485.

1958. Science, N.Y., 128, 1574.

1965. Ann. N.Y. Acad. Sci., 128, 231.

1962. Lancet, 1, 1315.

1962. J. Molec. Biol., 5, 109.

1938. J. Hyg., Camb., 38, 732.

1963. Nature, Lond., 200, 1126.

1965. Ann. N.Y. Acad. Sci., 128, 45.

1936. Zentbl. Bakt., Abt. I, Orig., 136, 221.

1965. Int. Bull. Bact. Nomencl. Taxon., 15, 109.

1962. J. Amer. Med. Assoc., 181, 38.

1962. Yale J. Biol. Med., 34, 560.

1956. J. Exp. Med., 103, 87.

1961. In Antimicrobial agents and chemotherapy, ed. by M. Finland and G. M. Savage, Detroit, p. 67. 
A Capsulate Staphylococcus aUREUS

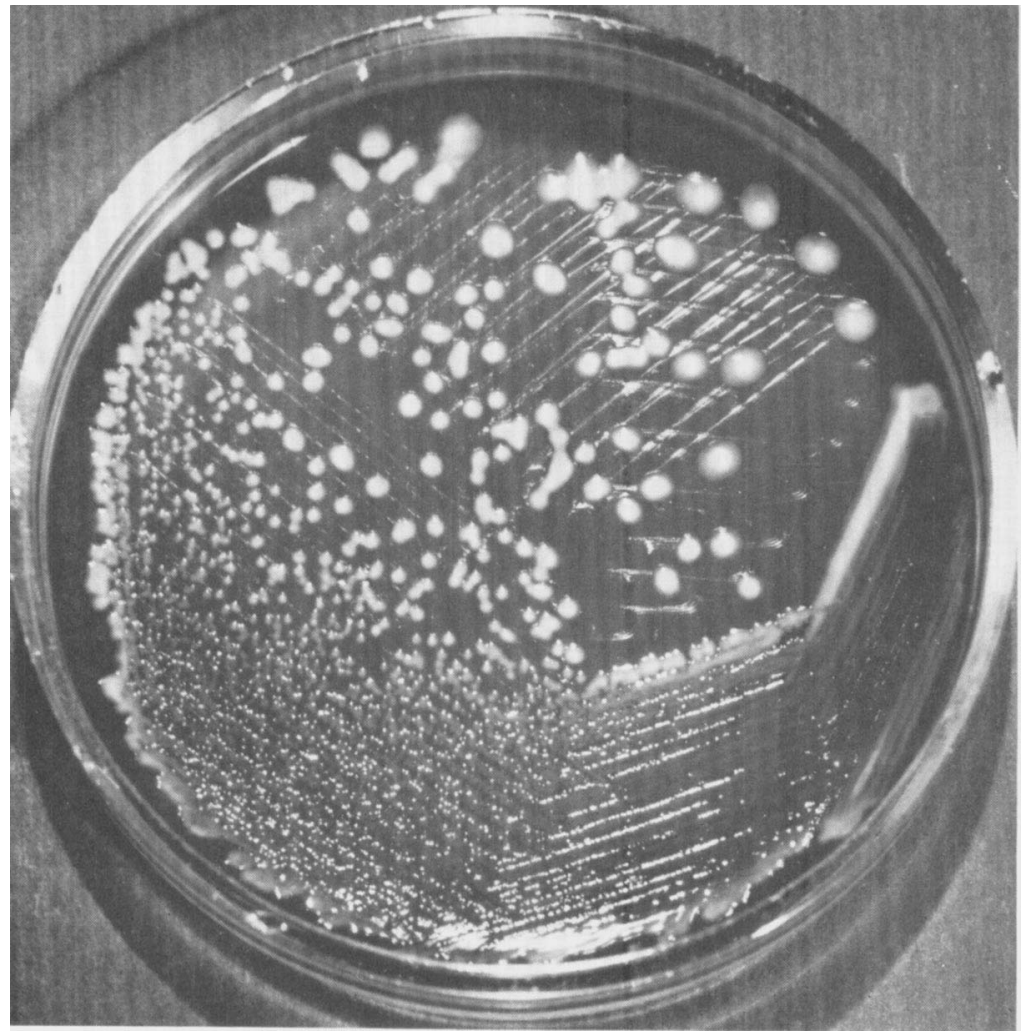

FIG. 1.-Blood agar culture of strain M after 24 hours' incubation at $37^{\circ} \mathrm{C} . \quad \times 1$. 
A CAPSUlate STAPHYLOCOCCUS AUREUS

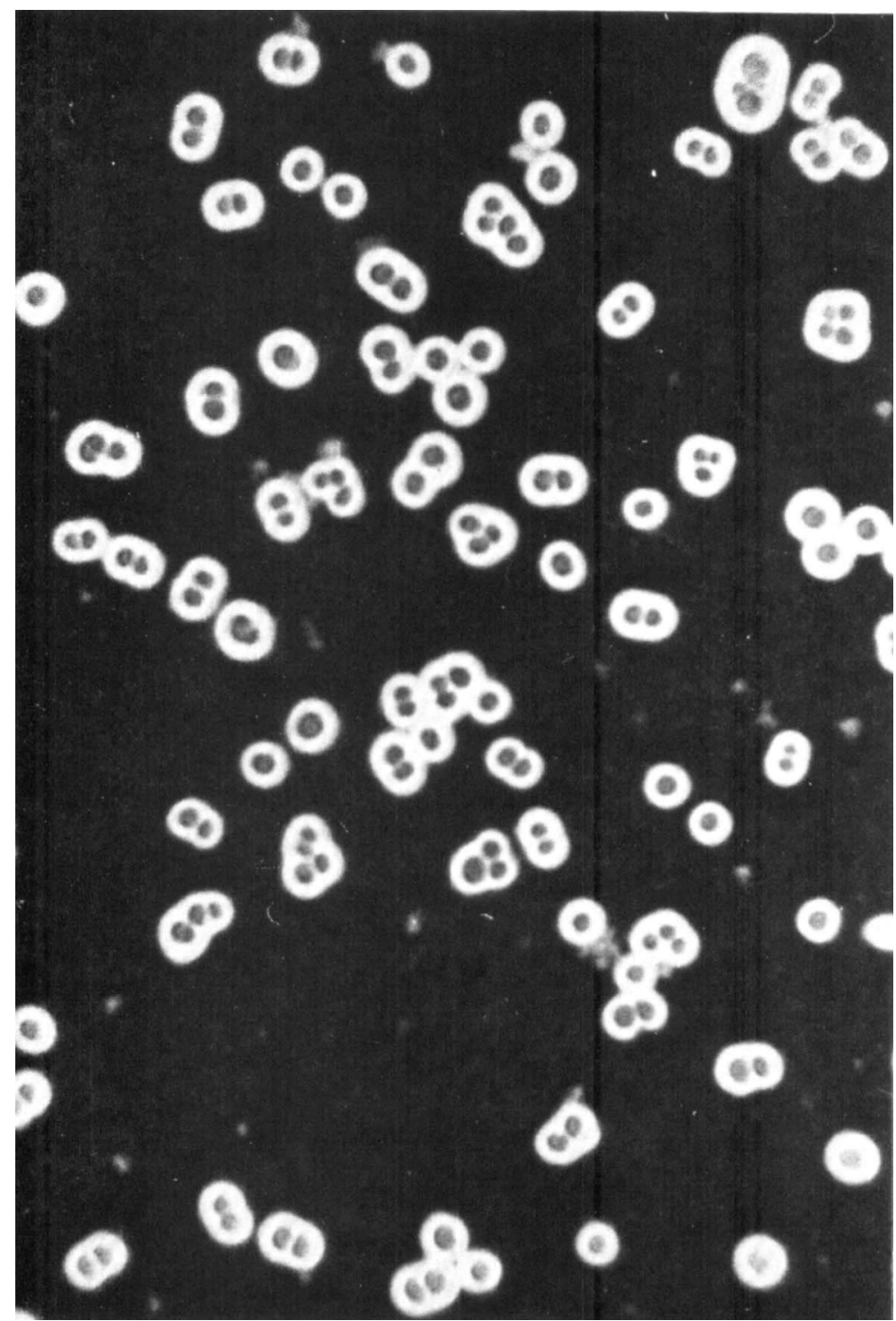

Fig. 2.-Cells of strain $\mathrm{M}$ from a $24-\mathrm{hr}$ blood agar culture. The cells were stained with 2 per cent. aqueous rose bengal and then suspended in India ink. $\times 1500$. 


\section{A capsulate Staphylococcus aureus}

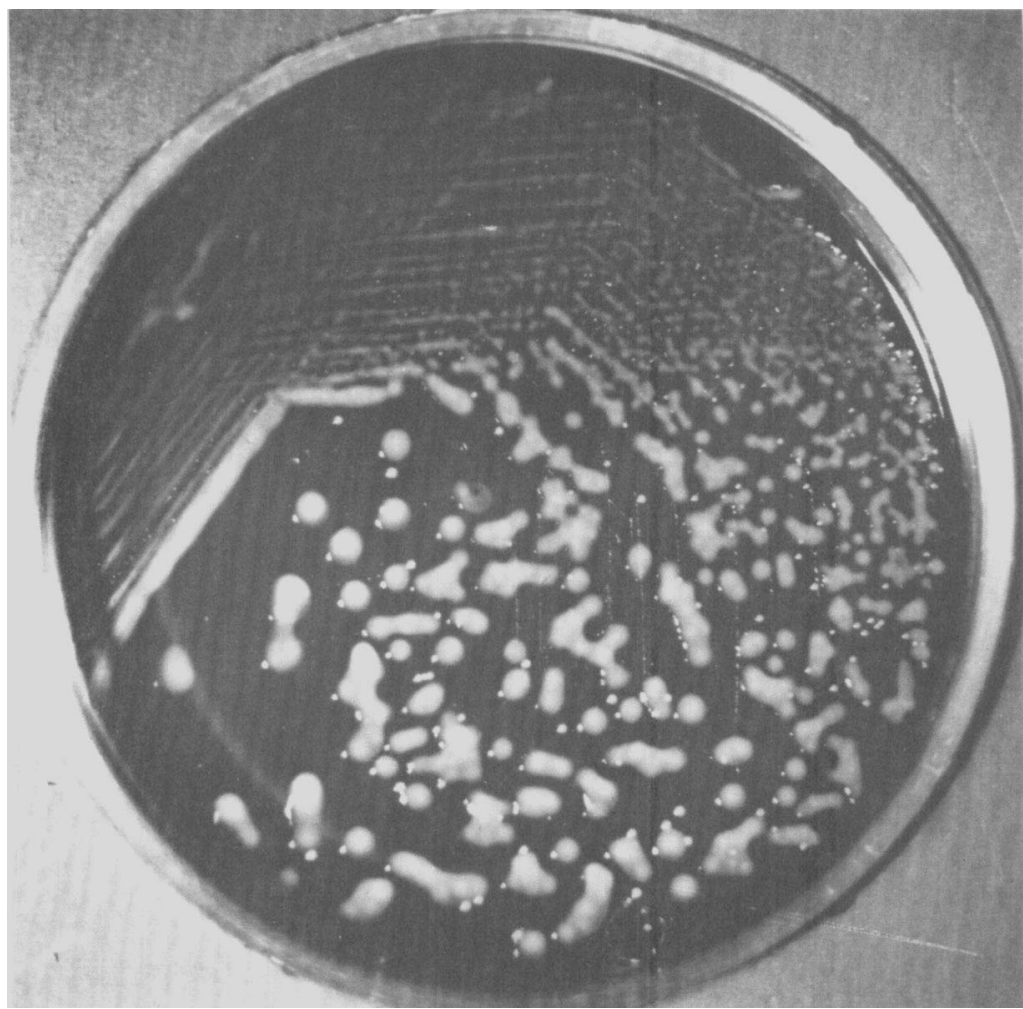

FIG. 3.-A 24-hr blood agar culture of peritoneal exudate from a mouse challenged intraperitoneally $48 \mathrm{hr}$ earlier with $4 \times 10^{9}$ colony-forming units of strain D. Large mucoid colonies, composed of capsulate organisms, and small non-mucoid colonies, composed of non-capsulate organisms, are present. $\times 1$. 